\title{
THE IMPORTANCE OF ATMOSPHERE AND SPATIALITY IN CREATING SOCIAL EXPERIENCES
}

\section{MARTIN BRANDT DJUPDRAET}

\section{ABSTRACT/ABSTRAKT:}

The aim of the article is to analyse the influence of atmosphere and reminiscence in the social space of the museum. In the 1990s, museum theorists drew attention to the fact that museum visitors play a part in constructing their museum visits and also focused on the importance of the social context in the museum visit. Using examples of interior at the Danish open-air museum Den Gamle By dated to 1950s and 1970s the article analyse how museum space and communications support both the visitors' experience of their own history and experiences, and the visit to the museum as a social experience. Both can help to strengthen the visitor's own identity and the learning process which can take place when visitors share their knowledge and experiences.

\section{Důležitost atmosféry a prostoru pro vytvoření společenských zážitků}

Cílem článku je analyzovat vliv atmosféry a vzpomínek ve společenském prostoru muzea. V devadesátých letech muzejní teoretikové poukazovali na skutečnost, že návštěvníci muzea mají podíl na vyznění návštěvy muzea a také se zaměřili na důležitost společenského kontextu při návštěvě muzea. $S$ využitím př́ikladu dánského skanzenu Den Gamle By s datováním do padesátých a sedmdesátých let článek analyzuje, jak muzejní prostor a komunikace podporují jak návštěvnický zážitek na základě vlastní historie a zkušeností, tak i návštěvu muzea jako společenský zážitek. Obojí může napomoci k posílení návštěvníkovy vlastní identity a procesu poznání, ke kterému může dojít, když návštěvníci sdílejí svoje znalosti a zážitky.

\section{KEYWORDS/KLÍČOVÁ SLOVA:} authenticity - remembrance dementia - social context - personal context

autenticita - vzpomínání demence - společenský kontext osobní kontext

Museums are stories. They are art, science, history, things that happened once upon a time, and traces of life. They are content.

An aspect that is just as important, however, is the visitors' own needs. The museum is a space that people choose in the belief that the museum can fulfil the individual visitor's personal and social needs. Museums can be used to tell people about who they are, and to show others their values and interests. Confirmation of one's own identity happens when there are others present, and experiences from the museum are shared. This type of use of the museum is thus linked to the people you visit the museum with, or to the people you talk to about the visit afterwards. In this way there are several aspects to a shared social experience at a museum. It can be

- a forum where basal social needs are met;
- a forum where visitors' social identity can be shown, and

- a forum where the museum's stories and contents are discussed.

The social museum experience meets both personal and social needs. This aspect of the use of museums is worth considering in the light of how it can be supported in the museum spaces and communications.

It is also worth bearing in mind that a normal visit to a museum is in fact a shared social experience. People rarely visit museums alone. Numerous surveys of how visitors use museums have documented that visiting a museum is a joint experience with other people. ${ }^{1}$

This article focuses on the museum as a social space, and will analyse

1 One of these surveys has collected figures nationwide since 2009 from the majority of Danish museums. The percentage for how many visit a museum in company with others varies from year to year, but lies between $91 \%$ and $95 \%$. LUNDGAARD, Ida Brændholt and Anna Maria FOLDGAST. National brugerundersøgelse 2011. Copenhagen: Kulturstyrelsen, 2012, p. 28; JENSEN, Jacob Thorek and Ida Brændholt LUNDGAARD. MUSEER - Borgere og Baredygtige Løsninger [online]. København: Kulturstyrelsen, 2015, p. 68 [accessed 2019-01-20]. Available from www: <https://slks.dk/publikationer/ museer-borgere-og-baeredygtige-loesninger/> ; Den nationale brugerundersøgelse for museer. Årsrapport 2017 [online]. København: Slots- og Kulturstyrelsen, September 2018, p. 6 [accessed 2019-01-20]. Available from www: <https:// slks.dk/fileadmin/user_upload/0_SLKS/ Dokumenter/Publikationer/2018/Den_nationale brugerundersoegelse 2017. Rapport.pdf $>$.

The same tendencies have also been registered in the USA, the UK, Australia and elsewhere: DIERKING, Lynn D. Museum as social learning. In LUNDGAARD, Ida Brændholt and Jacob

Thorek JENSEN. Museums: social learning spaces and knowledge producing processes. Copenhagen: Kulturstyrelsen - Danish Agency for Culture, 2013, p. 202. 
the influence of atmosphere and reminiscence in the social space. The cases used in the article are primarily taken from the Danish open-air museum Den Gamle By (The Old Town in Danish), where in recent years special focus has been directed to studying and developing the museum as a social space. ${ }^{2}$

\section{Theories of the museum as a social space}

In the 1990s, the museum theorists Kenneth Hudson, George Hein, Gaynor Kavanagh, Elaine Heuman Gurian and others drew attention to the fact that museum visitors play a part in constructing their museum visits. ${ }^{3} \mathrm{~A}$ visit to a museum should no longer only be understood on the basis of the objects and what the museum was showing, but should include and be seen from the angle of the visitors' own history and the agenda they brought with them to the museum. The social aspect of a visit to a museum was part of this extended understanding of the museum and the museum experience. Museum and learning researchers John H. Falk and Lynn D. Dierking emphasised this element in 1992 in the book The

2 This article was first presented as a lecture held in May 2018 at Centre of Museology at Masaryk University. I would like to thank Judita Matyášová, Denisa Brejchová, Komise pro práci s veřejností a muzejní pedagogiku AMG, Lucie

Jagošová and the Centre of Museology for making the visit at Masaryk University possible. I will also thank students at Centre of Museology for good response to my lecture, World Translation for help with translation and colleagues at Den Gamle By for useful discussions about the topics of the article.

3 GURIAN, Elaine Heuman. Noodling Around with Exhibition Opportunities. In KARP, Ivan and Steven D. LAVINE (eds.). Exhibiting cultures: the poetics and politics of museum display. Washington, D.C.: Smithsonian Institution Press, 1991, pp. 176-190; HEIN, George E. Learning in the museum. London: Routledge, 1998; HUDSON, Kenneth. The Museum Refuses to Stand Still. Museum international, 1998, vol. 50, no. 1, pp. 43-50; KAVANAGH, Gaynor. Making histories, Making Memories. In KAVANAGH, Gaynor (ed.). Making histories in museums. London: Leicester University Press, 1999, pp. 1-14.

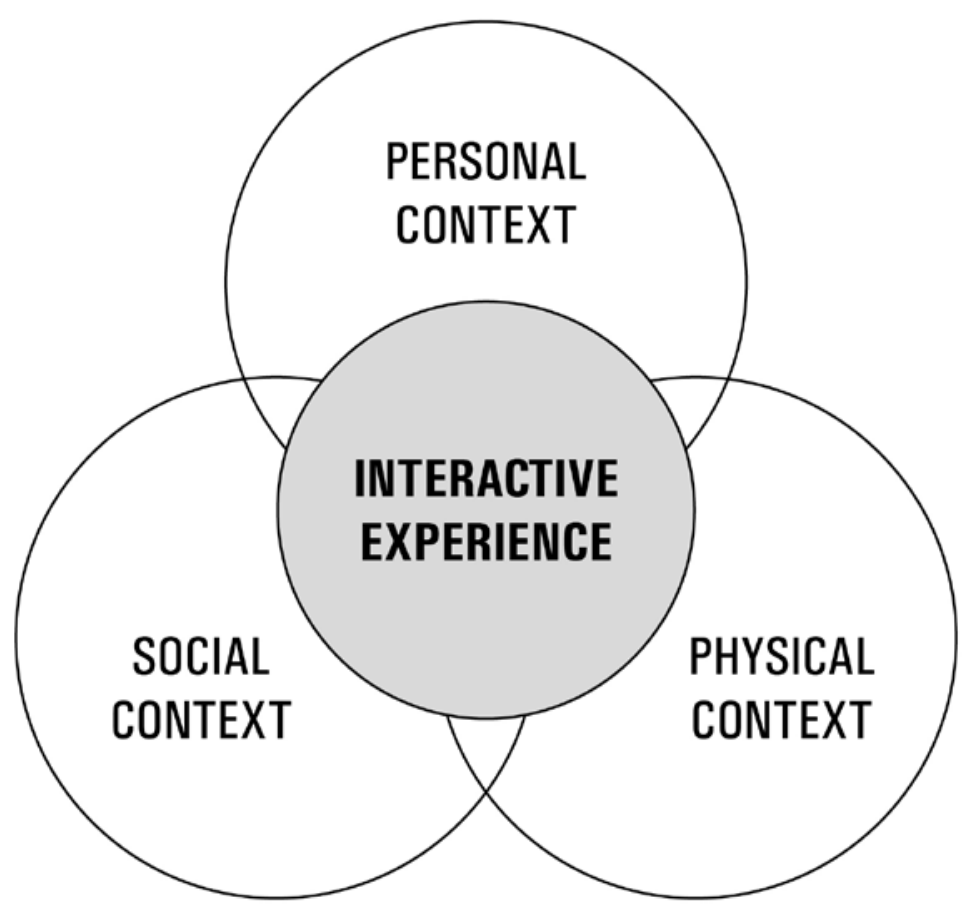

Fig. 1: Falk and Dierking's The Interactive Experience Model.

Museum Experience. ${ }^{4}$ In their book they introduced the Interactive Experience Model, where, besides the visitor's personal context and the physical space, they add the social context as a third important element in the museum experience. Later on, Falk and Dierking revised the model and renamed it the Contextual Model of Learning, and added more examples of the three aspects of the museum experience. ${ }^{5}$ The main point of the revised model remained the same, however: the museum experience has three primary contexts:

- The Personal context - your own history and experiences;

- The Social context - who is with you when you visit the museum, and the social setting and the

\footnotetext{
4 FALK, John H. and Lynn D. DIERKING. The Museum Experience. Washington, D.C.: Whalesback Books, 1992.

5 FALK, John H. and Lynn D. DIERKING. Learning from Museums: Visitor Experiences and the Making of Meaning. Oxford: AltaMira Press, 2000; FALK, John H. and Lynn D. DIERKING. The Museum Experience Revisited. New York: Routledge, 2013.
}

common stories you share with your companions;

- The Physical context - the setting, the room, the objects and other physical surroundings of the visit. ${ }^{6}$

Falk and Dierking's acknowledgement of the social aspect of the experience and informal learning at the museum are in line with the attention focused by Albert Bandura and David A. Kolb and other researchers on the social aspects of learning in the 1970s and 1980s, and in the growing field of investigations in recent decades into social learning theory and social learning spaces. ${ }^{7}$

6 FALK, John H. and Lynn D. DIERKING. The Museum Experience. Washington, D.C.: Whalesback Books, 1992, pp. 1-7; FALK, John H. and Lynn D. DIERKING. Learning from Museums: Visitor Experiences and the Making of Meaning. Oxford: AltaMira Press, 2000, p. 10; FALK, John H. and Lynn D. DIERKING. The Museum Experience Revisited. New York: Routledge, 2013, pp. 26-29.

7 BANDURA, Albert. Social learning theory. Englewood Cliffs, N. J.: Prentice-Hall, 1971; KOLB, David A. Experiential learning: experience as the source of learning and development. Englewood Cliffs, N. J.: Prentice-Hall, 1984. The literature 
In the terms of Falk and Dierking's model, museums can primarily control one of the contexts: The physical context. As this article will describe, however, by orchestrating the museum's spaces and content, it is also possible to influence the other two contexts.

\section{Den Gamle By}

The museum I will use as a case study in this article is Den Gamle By, which is where I work. Timewise, Den Gamle By is an open-air museum which shows the preindustrial period and periods in living memory. It was founded in 1914 as an open-air museum focusing on urban history and culture. Apart from being a national museum of urban history, since 2011 the museum has been specifically responsible for the history of Aarhus, the town where the museum is located. With 571,167 visitors in 2017, the museum was the third most visited museum in Denmark, and one of the major open-air museums in Europe.

Since 2007, the museum has also focused especially on showing the 20th century, and in particular the 1970s, which is a period with elements that many of the museum's visitors can recognise. The original part of Gamle By shows the time before 1900 . Today, the museum includes a smaller section showing the inter-war

on social learning includes among others: What is social learning? Ecology and Society [online]. 2010, vol. 15, no. 4 [accessed 2019-01-20]. Available from www: <http://www.ecologyandsociety.org/ vol15/iss4/resp1/>; Designing spaces for effective learning: A guide to 21st century learning space design [online]. Bristol, UK: Joint Information Systems Committee, 2006 [accessed 2019-0120]. Available from www: <https://webarchive. nationalarchives.gov.uk/20140703004833/http:// www.jisc.ac.uk/media/documents/publications/ learningspaces.pdf >; KELLY, Matthews E.

Victoria ANDREWS and Peter ADAMS. Social learning spaces and student engagement. Higher Education Research \& Development, 2011, vol. 30, no. 2 , pp. $105-120$.

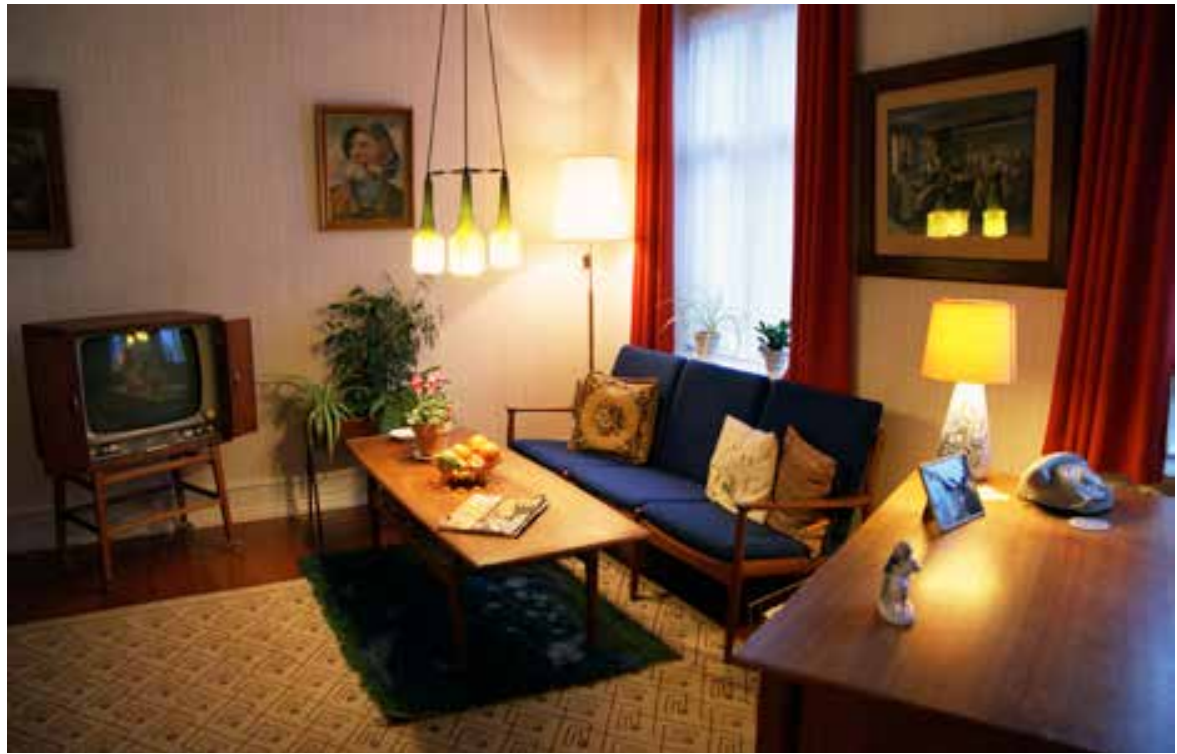

Fig. 2: One of the flats in the 1974 town district.

years and the modernity and mechanisation of that period. This part of the museum focus on the year 1927. A new section in an extension of the museum shows the welfare state in Scandinavia, and what life might have been like in Denmark in 1974. Thus Den Gamle By is part of a trend among several open-air museums in Scandinavia, the United Kingdom and the Benelux countries which have chosen to move forward in time and add on sections or buildings and interiors from the last part of the 20th century. ${ }^{8}$

By showing a period which many people can relate to, either through their own memories or through stories told by relatives, Den Gamle By and the other museums that follow the trend seek to make the museum relevant and up to date in the same way as the open-air museums originally were when they first opened at the end of the 19th century and beginning of the 20th. In the

\footnotetext{
8 This trend is described in RENTZHOG, Sten. Open Air Museums. The history and vision of a visionary idea. Stockholm: Carlson Bokförlag, 2007, pp. 328-342; RAVN, Thomas Bloch. Moderne tider på museum. In BAK, Lene et al (eds.). Kildekunst: historiske \& kulturhistoriske studier: festskrift til John T. Lauridsen. København: Museum Tusculanum, 2016, pp. 569-582.
}

words of John Williams-Davies, the former director at St Fagan's in Wales, in 2009: "When open-air museums first emerged around 1900 they were both radical and highly relevant institutions: they focused on the daily lives of ordinary people and their storytelling targeted the ordinary people."

In Den Gamle By we drew inspiration from this approach when we planned the new 1974 town district. It was our ambition to use ordinary everyday objects and environments to tell everyday stories about ordinary people in ordinary homes, which would never be listed buildings or special heritage settings. Up to 2019, seven buildings have been erected in that part of the museum, with eleven flats, a kindergarten and a number of shops and workshops: among other things there is a minimarket, a gynaecologist's clinic, a plumber's workshop, a moped workshop and a radio and television dealer's. ${ }^{10}$

\footnotetext{
9 WILLIAMS-DAVIES, John. Now Our History is Your History: The Challenge of Relevance for Open-Air Museums. Folk Life. Journal of Ethnological Studies, 2009, vol. 47, pp. 119-120.

10 There is a description of the various elements of the 1974 quarter in Den Gamle By in RAVN, Thomas Bloch. The Modern Town Project at Den Gamle By. Den Gamle By [Årbog], 2007, pp. 72-74;
} 
Altogether these buildings and interiors tell a wider story about the Scandinavian welfare system and lifestyle changes in the 1970s, but at the same time they are full of elements which bring back memories, and thus can be used as a setting where visitors can talk about their own lives and tell their own family histories. To have this effect, the settings must be recognizable, and this means that the environments must be authentic.

\section{Authenticity}

Museums contain art pieces and craftsmanship, objects and stories that are closely linked to real life and the creation of credibility through all these ways of presenting the past is vital for museums. Authenticity is all about credibility. Behind these concepts, authentic and credible, however, is a communication factor linked to what is perceived as credible and authentic. That means what the recipients consider important in understanding credibility and authenticity. Authenticity can lie in the object and the actual material, but objects can lose their power of communication if they no longer resemble what they once were, or can be put to their original use. An example of this can be seen in the Danish Viking Ship Museum in Roskilde. In the museum you can see the Viking ships that once carried the Vikings far and wide. The thousand-year-old waterlogged wooden planks make a strong statement, but they can no longer be used today in their original function for transport, or show, without the help of metal supports, what the Viking ships looked like.

RAVN, Thomas Bloch. Den Gamle By. History and Future. Aarhus: Den Gamle By, 2009, pp. 27-46; RAVN, Thomas Bloch. Moderne tider på museum. In BAK, Lene et al (eds.). Kildekunst: historiske \& kulturhistoriske studier: festskrift til John

T. Lauridsen. København: Museum Tusculanum, 2016, pp. 582-588 and Timetravel: Den Gamle By. Aarhus: Den Gamle By, 2018, pp. 106-129.
In the museum's harbour there are reconstructions of the ships, which show what the originals once looked like. They are built in the same way from the same materials, and can sail in the same seas as the original ships. Depending on which criteria are applied for authenticity, both the ships in the museum and those in the harbour can be called authentic.

\section{In 1977, the United Nations}

Educational, Scientific And Cultural Organization (UNESCO) drew up Guidelines for the World Heritage Committee. ${ }^{11}$ The document sets out how cultural monuments are to be assessed, and authenticity is the most important criterion. In the original document there were four markers of authenticity: design, materials, workmanship and setting, but the guidelines are continually updated, with focus on the concept of authenticity. ${ }^{12}$ Authenticity and credibility can be perceived in different ways, depending on considerations of materiality, function or the visual impression. These considerations

11 Operational Guidelines For The World Heritage Committee 1977 (CC-77/CONF.001) [online]. United Nations Educational, Scientific and Cultural Organization (UNESCO) [accessed 2019-01-20]. Available from www: <https://whc. unesco.org/archive/opguide77a.pdf $>$.

12 In the most recent version of the document Operational Guidelines for the Implementation of the World Heritage Convention from 2017 the criteria for authenticity are: form and design; materials and substance; use and function; traditions, techniques and management systems; location and setting; language, and other forms of intangible heritage; spirit and feeling and other internal and external factors. The Operational Guidelines for the Implementation of the World Heritage Convention 2017 (41 COM 11) [online]. United Nations Educational, Scientific and Cultural Organization (UNESCO), Chapter ILE, paragraph 82 [accessed 2019-01-20]. Available from www: <https://whc.unesco.org/en/ guidelines/ $>$. An important study in connection with clarifying the concept of authenticity was the Nara Document on Authenticity, a declaration put forward jointly in 1994 by UNESCO (the United Nations Educational, Scientific and Cultural Organization), ICCROM (the International Centre for the Study of the Preservation and Restoration of Cultural Property) and ICOMOS (International Council on Monuments and Sites). The Nara Document on Authenticity [online]. International Council on Monuments and Sites (ICOMOS), 1994 [accessed 2019-01-20]. Available from www:

$<$ https://www.icomos.org/charters/nara-e.pdf $>$. are very important in relation to the museums as a whole, their interiors, and the power of the statements which can be made in exhibitions and environments. ${ }^{13}$

An essential element in the 1974 quarter in Den Gamle By is the creation of credible exteriors and interiors. One way of doing it is to focus not only on the material authenticity (that the objects could have existed in 1974), but also to focus on process authenticity (that the buildings, furniture, wallpaper and other items/elements are made through the right processes) and visual authenticity (making elements look real, for instance by using replicas of objects). ${ }^{14}$

An example is the minimarket in the 1974 quarter. In order to furnish it credibly, the choice was made to focus on visual authenticity rather than material authenticity. The original packaging from everyday items that could be collected had become discoloured, and the objects appeared more or less

13 Frederik Stjernfelt puts the museological conflicts in the concept into perspective in an article from 2009. The article is a revision of a keynote speech given by professor Stjernfelt at an Association of European Open Air Museums conference in 2007, on the theme of authenticity and relevance. STJERNFELT, Frederik. Authenticities and their conflict: Genuine challenges of museology. In RAVN, Thomas Bloch and Elsebeth Aasted SCHANZ (eds.). Authenticities and Relevance: Report from the 24th Conference in the Association of European Open Air Museums, Den Gamle By, Aarhus, Denmark 2009. Aarhus: Den Gamle By, 2011, pp. 40-59.

14 How to distinguish between the different concepts of authenticity from a museum's point of view is described by ROEDE, Lars. Flytting - forkastelig eller forsvarlig? Fortidsvern Medlemsblad for Förtidsminneforeningen, 1999, vol. 25, no. 4, pp. 17-18 and ROEDE, Lars. Kopi og original - flytting og autentisitet. In AMUNDSEN, Arne Bugge, Bjarne ROGAN and Margrethe C. STANG (eds.). Museer i fortid og nåtid. Essays i museumskunnskap. Oslo: Novus forlag, 2003, pp. 124-132. Visual and process authenticity are also among the eight elements on which UNESCO bases its definition of authenticity: The Operational Guidelines for the Implementation of the World Heritage Convention 2017 (41 COM 11) [online]. United Nations Educational, Scientific and Cultural Organization (UNESCO), Chapter ILE, paragraph 82 [accessed 2019-01-20]. Available from www: < https://whc.unesco.org/ en/guidelines/>. 
worn and faded. It would not be credible or create the right mood and atmosphere to walk into a modern supermarket in 1974 and find products that did not look completely new. It was therefore necessary to recreate the packaging. In the chosen process, packaging such as milk cartons and packing of breakfast cereal were collected and scanned.

The scans were then colour-corrected, to restore the original appearance of the objects from the 1970s, and finally the scans were printed on materials like the original packaging materials. It was a laborious process, but it was the best way to give the museum visitors the feeling of going into a supermarket in 1974. The visual authenticity is recognised by the visitors, and reminds them of earlier visits to supermarkets, and perhaps of situations earlier in their own lives.

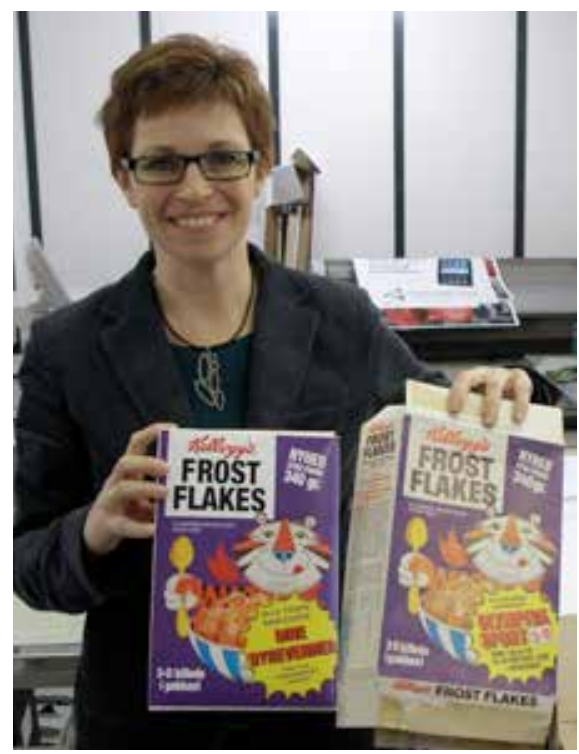

Fig. 3: Original packing of breakfast cereal and recreated packaging used in the minimarked from 1974.

\section{Promoting reminiscence}

For some years, Den Gamle By has been working with elderly people with dementia. This activity has especially targeted the memories

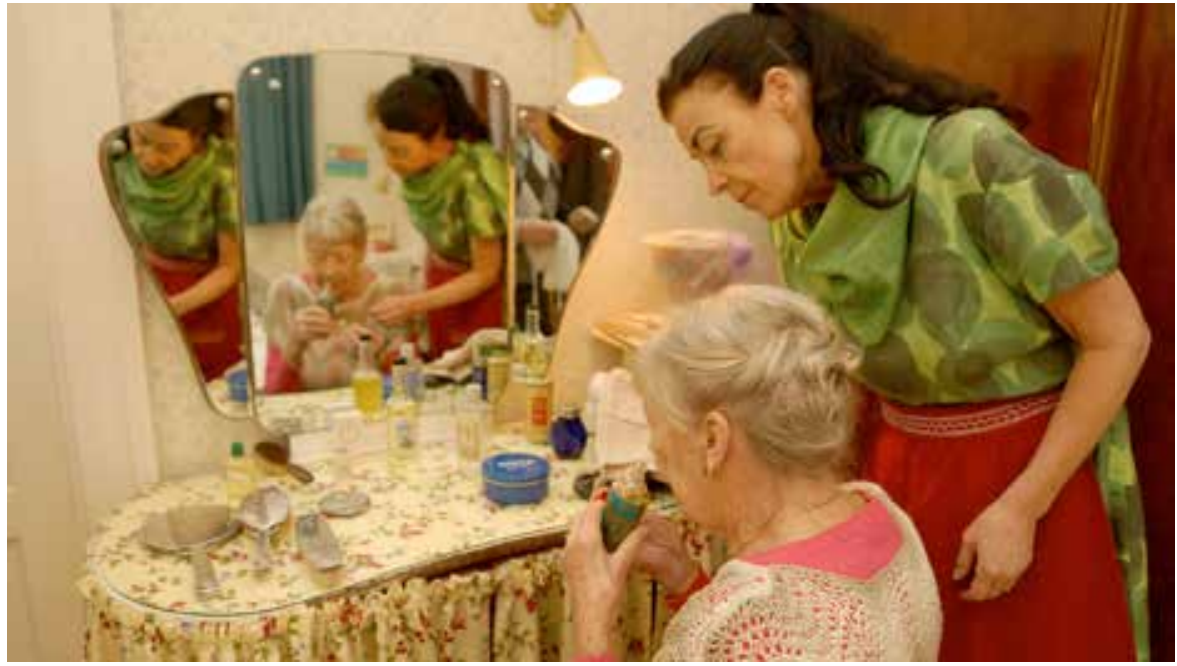

Fig. 4: Course in the House of Memory in Den Gamle By.

of visiting groups - both their collective memories, if they had any, and each person's individual memories.

In 2012, Den Gamle By opened the House of Memory, a flat specially furnished for sessions with dementia patients. It is a threeroom flat with accessibility for wheelchair users, a functional toilet and kitchen, two living rooms, a hallway and a bedroom.

As collaborating partners, memory researchers from Aarhus University and the Department of Health and Care at Aarhus Municipality assisted with their knowledge. The furnishings in the flat date from the 1950s, which research has shown to be the period when the strongest memories were formed by patients who suffer from dementia today, and thus there is a greater chance of evoking the elderly people's memories of this period. ${ }^{15}$ The programmes in the flat are attended by four to eight elderly people with helpers from a nursing home. They are usually very silent and introverted when they arrive. An employee at Den Gamle By welcomes them, playing

15 FROMHOLT, Pia et al. Life-narrative and word -cued autobiographical memories in centenarians: Comparisons with 80year-old control, depressed, and dementia groups. Memory, 2003, vol. 11, no. 1 , p. 84 . the role of the lady who lives in the flat, and she apologises for being late with their coffee and cake. The elderly visitors liven up and begin to register their surroundings, which they have often shut out: here is a familiar smell, familiar furnishings and a situation they know. The ladies help in the kitchen, and the men find seats in the living room. Coffee and cake are ready in the dining room, and while household objects from the 1950s are passed round, the elderly guests focus and become interested. After about two hours, the session ends with singing, and as the guests leave the flat, it may be difficult to see which of them suffer from dementia. Here in the past, they return to the present for a couple of hours. ${ }^{16}$

The flat and the methods used in connection with it have also been used in recent years to train

16 The reminiscence programme in Den Gamle By and the ideas behind these programmes are described in KRYGER, Birgitte, Henning LINDBERG and Tove Engelhardt MATHIASSEN. Erindringsformidling - brobygning mellem det sociale og det kulturelle. Den Gamle By [Årbog], 2005, pp. 68-73; RAVN, Thomas Bloch. Meget mere end museum. Den Gamle By [Årbog], 2012, pp. 23-29; and LINDBERG, Henning. The House of Memory. In HANSEN, Anna, Sofia KLING and Jakoba Sraml GONZALEZ (eds.). Creativity, Lifelong Learning and the Ageing Population. Fornvårdaren. Vol. 34. Östersund: Jamtli Förlag, 2013, pp. 94-101. 
future employees in the care sector. Several training centres for health sector staff around Den Gamle By arrange visits as a mandatory part of their training programmes. The course has two main objectives:

1. To equip the students to help elderly people suffering from dementia to retrieve their memories.

2. To give the students an insight into what Denmark looked like from 1940 to 1960 . That was the period when the elderly people were young. How did Danes live? What did they eat? What clothes did they wear? How did they amuse themselves? This is especially important for students who may have grown up in ethnic cultures that are different from the traditional Danish culture.

The courses are structured so that the students experience for themselves what happens when memories are evoked, and they learn methods that will enable them to promote reminiscence themselves. The students are shown every day household objects they can remember, and in Den Gamle By they visit one of the flats from 1974, in order to give them their own experience of recognition and remembering. They also visit the House of Memory, where they meet an employee who tells them about the programmes in the flat for elderly people with dementia. ${ }^{17}$

\section{Surveys of the effects of promoting reminiscence}

In Den Gamle By, the method used for promoting reminiscence is built on evoking events and experiences from a person's own life. Since the psychologist R. N. Butler wrote

17 The programmes are described in Part 4 Courses for professional care staff. In HANSEN, Anna (ed.). Reminiscence in open air museums. Results from the Erasmus + project Active Ageing and Heritage in Adult Learning, Östersund: Jamtli Förlag, 2017, pp. 46-47.
"The life-review: An interpretation of reminiscence in the aged" in 1963, this reminiscence method has been widely used in many institutions. ${ }^{18}$ A number of research reviews conclude that this method has a positive influence on the elderly people's emotional state, and results in improved function and well-being. ${ }^{19}$

An important collaborator with Den Gamle By's House of Memory project has been CON AMORE, the Center on Autobiographical Memory Research at Aarhus University. Apart from discussing and exchanging ideas about research into reminiscence and gerontology, the centre and the museum have also collaborated on research projects on the significance of the museum space for the elderly people's memory and well-being. One of the projects was to investigate the difference between dementia patients' memories evoked during a visit to the House of Memory in Den Gamle By, compared with memories evoked in an everyday environment at a care centre. ${ }^{20}$ The

18 BUTLER, R. N. The life review: an interpretation of reminiscence in the aged. Psychiatry, 1963, vol. 26, no. 1, pp. 65-76 and LATHA, K. S. et al. Reminiscence Therapy: An Overview. Middle East Journal of Age and Ageing, 2014, vol. 11, no. 1, p. 20

19 On the effect of the reminiscence method: Reminiscence therapy for dementia. Cochrane Database of Systematic Reviews [online]. 2005, Issue 2, Art. No.: CD001120 [accessed 2019-01-20]. Available from www: <https://www. cochranelibrary.com/cdsr/doi/10.1002/14651858. CD001120.pub2/>; SUBRAMANIAM, Ponnusamy and Bob WOODS. The impact of individual reminiscence therapy for people with dementia: systematic review. Expert review of neurotherapeutics, 2012, vol. 12, no. 5, pp. 545-555; HUANG, Hui-Chuan et al. Reminiscence Therapy Improves Cognitive Functions and Reduces Depressive Symptoms in Elderly People With Dementia: A Meta-Analysis of Randomized Controlled Trials. Journal of the American Medical Directors Association, 2015, vol. 16, no. 12, pp. 1087-1094 and DEMPSEY, Laura et at. Reminiscence in dementia: A concept analysis. Dementia, 2014, vol. 13, no. 2, p. 182. The last of these is an overview of the scientific use of the term reminiscence and related concepts.

20 The study is published in Turning back the hands of time: Autobiographical memories in dementia cued by a museum setting. Consciousness and Cognition, 2013, vol. 22, no. 3, pp. 1074-1081. participants in this study had all been diagnosed with Alzheimer's disease, and in the study, both at Den Gamle By and at the care centre, the objects passed round were the same type, representing situations from daily life and special occasions. The objects at the museum dated from the time when the participants were young, while the objects at the care centre were modern. There was an older model of a telephone as opposed to a mobile phone, or old-fashioned and modern cards commemorating confirmation in church.

The conclusion was that there was no great difference in recognition of the old and the new objects, but the study showed clearly that during sessions at Den Gamle By, more memories were evoked by the older objects, and the depth and amount of detail in the reminiscences was far greater.

Another project carried out by CON AMORE led to the conclusion that continued visits to the House of Memory brought back more memories with greater detail. ${ }^{21}$ A group of elderly patients diagnosed with Alzheimer's disease visited the House of Memory at Den Gamle By five times in the course of five weeks, and their reminiscences were tested before and after the visits. The findings clearly showed a greater degree of memory after a visit, with the memories evoked in more detail. The project also included a test group who did not visit the museum, and did not show the same striking increase.

These two projects have helped to establish that autobiographical memories are strengthened by the programmes in Den Gamle By. In another project, Active Ageing and

21 The study is published in Five weeks of immersive reminiscence therapy improves autobiographical memory in Alzheimer's disease. Memory, 2018, 08. 09. 2018, pp. 1-14. 
Heritage in Adult Learning, in which Aarhus University also took part, the focus was more on well-being resulting from visits to the House of Memory than on memories.

\section{Active Ageing and Heritage in Adult Learning}

Active Ageing and Heritage in Adult Learning was organised with funding from the Erasmus+ programme from 2015 to 2017, and its main objectives were:

- to develop programmes for elderly people suffering from dementia;

- to develop programmes for relatives of dementia sufferers;

- to develop programmes for care staff who work with this group;

- to evaluate the type of programme for elderly dementia patients which Den Gamle By and several other open-air museums had started to organise.

The collaborating partners in the project, besides Den Gamle By, were the Jamtli museum in Sweden, the Beamish museum in the UK, the Szabadtéri Néptrajzi Muzeum in Hungary and Maihaugen in Norway, as well as the Linneaus University in Sweden, the University of Newcastle upon Tyne in England and Aarhus University in Denmark. ${ }^{22}$

The universities taking part in the project have previously studied links between cultural offers and health, and their role in the project was to design the evaluation of the effects of the programmes and to be responsible for carrying out the evaluation. A total of 127

22 There is a description of the project, and it's results, in HANSEN, Anna (ed.). Reminiscence in open air museums. Results from the Erasmus+ project Active Ageing and Heritage in Adult Learning. Östersund: Jamtli Förlag, 2017.

\section{Well-being compared to usual}

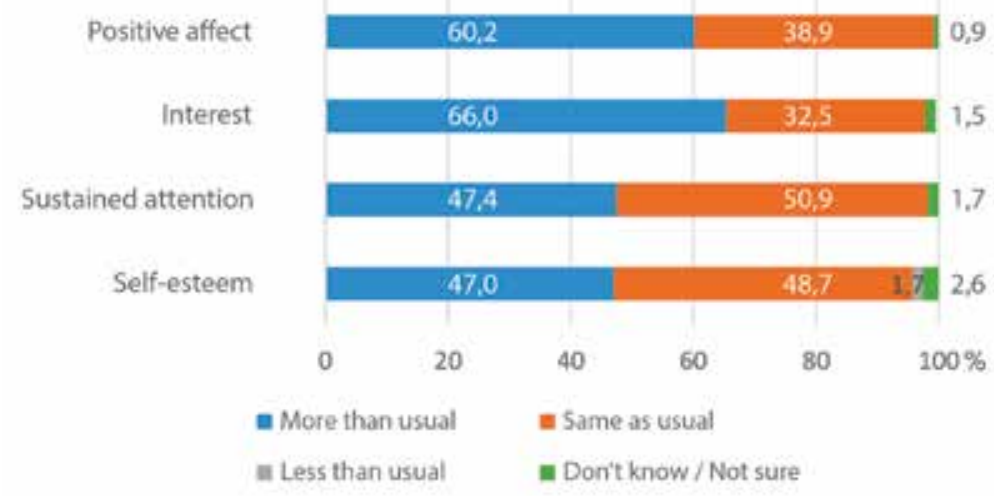

Well-being during sessions

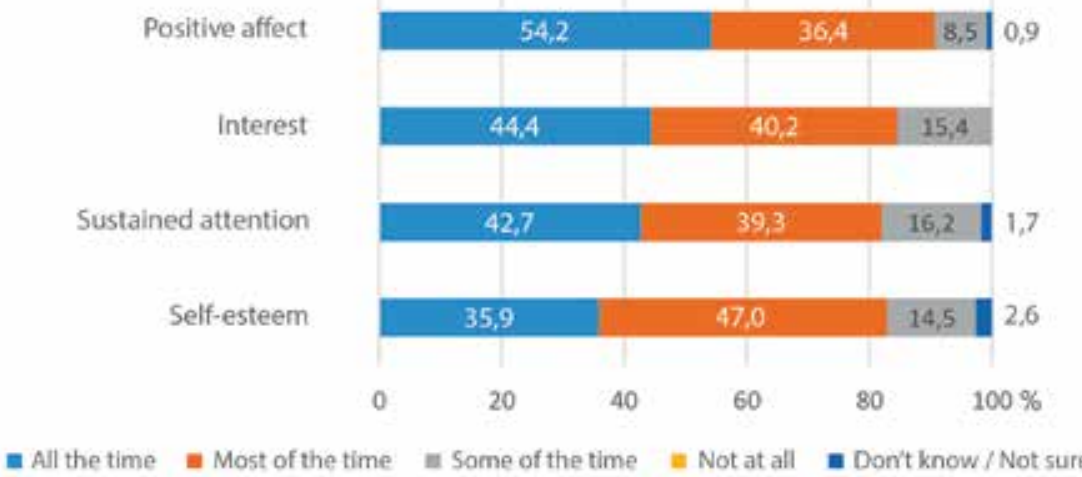

Fig. 5: Result of the quantitative data

persons with dementia (PwD) were observed, and 75 accompanying carers (AC) also took part in the study. ${ }^{23}$ An evaluation of how a cultural heritage environment affected dementia sufferers has never before been carried out with such a large number of observed or contributing individuals.

The Greater Cincinnati Chapter Well-Being Observation Tool (GCCWOT) was selected as the tool for the survey. GCCWOT registers indicators for domains of well-being, such as interest, sustained attention, pleasure, self-esteem and negative affect or sadness. These

23 Part 2: Evaluation of reminiscence activities. In HANSEN, Anna (ed.). Reminiscence in open air museums. Results from the Erasmus + project Active Ageing and Heritage in Adult Learning. Ötersund: Jamtli Förlag, 2017, p. 22. indicators are re-formulated to a questionnaire format that was suitable for use in this project.

Each domain was carefully defined using the behavioural indicators that were used in the original GCCWOT, enabling the accompanying carers (AC) a tool to assess the PwD participants' experiences during a session. Interest, for example, was defined as "Verbally or physically indicates interest in others or own work; Engages with others without prompting (e. g. by smiling, making eye contact, chatting, accepting/ giving support, etc.)."24

24 Archive of Den Gamle By. Active Ageing \& Heritage in Adult Learning. Questionnaire A Accompanying Carers. A description of the study and the study method can be found in Part 2: Evaluation of reminiscence activities. In HANSEN, Anna (ed.). Reminiscence in open air museums. 
The results of the assessment were striking: $90.6 \%$ of PwD expressed / showed positive affect all the time or most of the time. $80.0 \%$ of PwD could maintain sustained attention all the time or most of the time. $84.4 \%$ of PwD showed interest through contact to others all the time or most of the time, and $82.9 \%$ of PwD expressed self-esteem in words or in body language all of the time or most of the time.

In the study, the ACs were asked to compare the PwDs' state of mind during the visit with their normal state of mind. The ACs assessed that for $60.2 \%$ of the PwDs' the positive emotional impact was greater than usual. With interest the result was the same (greater than usual) for $66.0 \%$. For sustained attention the result was $47.4 \%$ and for self-esteem $47.0 \% .^{25}$ A factor that should be taken into consideration in this part of the study is that the ACs who filled in the questionnaires were carers or family members who play a part in the dementia patients' daily state of mind. This part of the study will, therefore, also be an assessment of their own role as carers, which may influence their answers. Unfortunately this cannot be investigated more closely with the material collected. On the whole, however, the replies show that the elderly people's well-being was

\footnotetext{
Results from the Erasmus + project Active Ageing and Heritage in Adult Learning, Östersund: Jamtli Förlag, 2017, pp. 17-37. The elements of GCCWOT are described in RENTZ, Clarissa A. Memories in the Making(C): Outcome-based evaluation of an art program for individuals with dementing illnesses. American Journal of Alzheimer's Disease \& Other Dementias, 2002, vol. 17, no. 3, pp. 175-181; KINNEY, Jennifer M. and Clarissa A. RENTZ. Observed well-being among individuals with dementia: Memories in the Making $($, an art program, versus other structured activity. American Journal of Alzheimer's Disease and Other Dementias, 2005, vol. 20, no. 4, pp. 220-227.

25 The quantitative data from the study is presented in HANSEN, Anna (ed.). Reminiscence in open air museums. Results from the Erasmus+ project Active Ageing and Heritage in Adult Learning. Östersund: Jamtli Förlag, 2017, Appendix 1, pp. 75-79.
}

better during visits to the museum than their general condition.

In addition, the ACs were asked in the survey to write down their observations as free text. These were typical comments:

\section{"- A specific object can lead to reminiscence. E. g. a picture of a soldier.}

\section{- Seeing everyone engaging. - The smiles on the participants' faces.}

\section{- The chatter and the way everyone was included.}

- To hear how the participants cheered up and talked about the old days.

\section{- An experience where one of our residents talked like never before." ${ }^{26}$}

A part of the study were short, semi-structured interviews held with the PwDs, who were asked how they felt about the session, and what particularly they liked or did not like. The interviews showed that, in spite of their illness, the PwDs could certainly reflect on their experience. In several interviews they clearly expressed that the visit had brought back memories, and that these memories had helped to support the person's original identity, from before autobiographical memories, and thus identity had been weakened by disease. As one of the participants at a session in Den Gamle By put it: "I' $m$ still really sorry now that my wife was not there that day. She thinks I' $m$ off my head." 27

\footnotetext{
26 Cueing autobiographical memory retrieval in people with dementia. Do museum-based reminiscence sessions promote wellbeing in people with dementia? Poster P01.45 at The 26th Alzheimer Europe Conference (26AEC). Copenhagen 2016.

27 Archive of Den Gamle By. Active Ageing and Heritage in Adult Learning Interview at a reminiscence session held in Den Gamle By on 5 April 2016. The significance of these programmes
}

Reminiscence is clearly present, but the interviews also show that in fact the elderly people reflect over all of the holistic social experience. This is summarised in the project report: "The diversity of moments and experiences that PwDs talked about also opens up the possibility that, for the participants, the act of reminiscing may not be of central importance but may be one of several elements, each of which add value to the embodied, social interactions which these sessions foster." 28

The reminiscence sessions in Den Gamle By and at the other museums in the Active Ageing and Heritage in Adult Learning project are powerful examples of the impact which the museum's cultural historical spaces can have on visitors. It is rare for a group of visitors to be observed in such detail as in this project, and it contributes valuable data on what happens in the space comprised by the museum and a museum visit.

The interviews with the elderly people show that reminiscence occurs, which is also in line with the studies carried out by CON AMORE in collaboration with Den Gamle By. The study shows, however, that it is not only reminiscence, but the whole of the experience and the social element that are of great importance. The observations of the AC show clearly that the elderly people are sociable during the visit $(82.9 \%)$ and this is confirmed by their comments: (e. g. "Seeing everyone engaging" and "The chatter and the way everyone was included"). The social interaction during the sessions was also emphasized in the project

\footnotetext{
for identity is discussed and analysed in the light of the history didactic field historic consciousness (Geschichtsbewusstsein) in DJUPDRÆT, Martin Brandt. Historiebevidsthed hos demente. Kulturstudier, 2018, vol. 9, no. 1, pp. 51-54

28 Part 2: Evaluation of reminiscence activities. In HANSEN, Anna (ed.). Reminiscence in open air museums. Results from the Erasmus + project Active Ageing and Heritage in Adult Learning. Östersund: Jamtli Förlag, 2017, p. 33.
} 


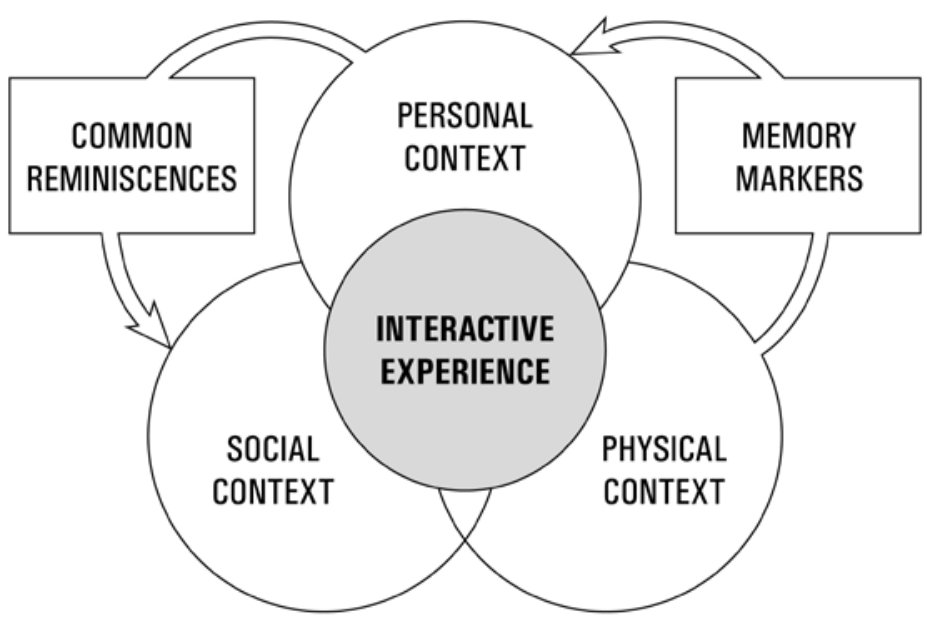

Fig. 6: Interaction between the contexts in Falk and Dierking's Interactive Experience Model.

report in the summing up of the interview with the PwD.

\section{Discussion and conclusions}

The chosen examples show possible connections between the museum spaces, the visitors' own personal histories and approach to the visit and the social experience and context which the museum also is.

In both the 1974 town district in Den Gamle By and in the museum's 1950s House of Memory for PwD, conscious efforts have been made to achieve visual and process authenticity which will evoke memories, and can thus be used to influence and bring back memories from the visitors' autobiographical memory.

\section{Using Falk and Dierking's} Interactive Experience Model and its three concepts, the psychical context, the personal context and the social context, I will describe the interaction which can be instigated between the museum space and the personal and social spheres, through the exhibitions referred to, making considerable use in their presentation of visitors' own memories and common memories.
Through the psychical context (the exhibitions), the museum seeks deliberately to create recognition and evoke memories. These are not only personal memories, but also elements with the nature of collective memories - the visitors' shared memories of the period. In this way, the psychical context can help to steer the visitors' common memory and reminiscences in a particular direction, thus providing subjects from their personal context which enable them to put into words and emphasise the elements in their shared experiences and understanding the social context.

To summarise: The atmosphere at the museum influences the social space. In the chosen case from Den Gamle By, the influence comes from creating an atmosphere and having objects which the guests can remember from their own lives, which bring back memories, that are shared and talked about in the social space. Through the choice of object and furnishings in Den Gamle By, we can influence visitors and their awareness, so that they think of particular personal memories, which they talk about with others, creating a common understanding. What Falk and
Dierking described as personal contexts in the visitor's museum experience are elements which the museum can influence deliberately. This influence can then strengthen the visitors' social experience of the museum space.

The selected examples deal with periods in time which visitors have lived through themselves, but the method can undoubtedly be transferred to other topics dealt with by the museum. It is necessary to focus on stories and subjects which visitors can relate to, and create a space and an ambience that makes individual visitors want to share their own experiences with other visitors to the museum. When this happens, the museum space and communications support both the visitors' experience of their own history and experiences, and the visit to the museum as a social experience. Both can help to strengthen the visitor's own identity and the learning process which can take place when visitors share their knowledge and experiences.

\section{BIBLIOGRAPHY:}

Archive of Den Gamle By. Active Ageing \& Heritage in Adult Learning. Questionnaire A - Accompanying Carers (Unpublished material).

Archive of Den Gamle By. Active Ageing and Heritage in Adult Learning Interview at a reminiscence session held in Den Gamle By on 5 April 2016 (Unpublished material).

BANDURA, Albert. Social learning theory Englewood Cliffs, N. J.: Prentice-Hall, 1971. ISBN 0-13-816751-6.

BUTLER, R. N. The life review: an interpretation of reminiscence in the aged. Psychiatry, 1963, vol. 26, no. 1, pp. 65-76. https://doi.org/10.1080/00332747.19 63.11023339

Cueing autobiographical memory retrieval in people with dementia. Do museum-based reminiscence sessions promote wellbeing in 
people with dementia? Poster PO1.45 at The 26th Alzheimer Europe Conference (26AEC). Copenhagen 2016.

DEMPSEY, Laura et at. Reminiscence in dementia: A concept analysis. Dementia, 2014, vol. 13, no. 2, pp. 176-192. https:// doi.org/10.1177/1471301212456277

Den nationale brugerundersøgelse for museer. Årsrapport 2017 [online]. København: Slots- og Kulturstyrelsen, September 2018 [accessed 2019-01-20]. Available from www: <https://slks.dk/fileadmin/ user_upload/0_SLKS/Dokumenter/ Publikationer/2018/Den_nationale_ brugerundersoegelse_2017._Rapport. pdf $>$.

Designing spaces for effective learning: A guide to 21st century learning space design [online]. Bristol, UK: Joint Information Systems Committee, 2006 [accessed 2019-01-20].

Available from www: <https:// webarchive.nationalarchives.gov. uk/20140703004833/http://www.jisc. ac.uk/media/documents/publications/ learningspaces.pdf $>$.

DIERKING, Lynn D. Museum as social learning. In LUNDGAARD, Ida Brændholt and Jacob Thorek JENSEN. Museums: social learning spaces and knowledge producing processes. Copenhagen: Kulturstyrelsen - Danish Agency for Culture, 2013, pp. 198-215. ISBN 978-87-91298-97-4.

DJUPDRÆT, Martin Brandt. Historiebevidsthed hos demente. Kulturstudier, 2018, vol. 9, no. 1, pp. 29-61.

FALK, John H. and Lynn D. DIERKING. The Museum Experience. Washington, D.C.: Whalesback Books, 1992. ISBN 0-929590-06-6.

FALK, John H. and Lynn D. DIERKING. Learning from Museums: Visitor Experiences and the Making of Meaning. Oxford: AltaMira Press, 2000. ISBN 0-7425-0295-3.

FALK, John H. and Lynn D. DIERKING. The Museum Experience Revisited. New York: Routledge, 2013. ISBN 978-1-61132-045-9.

Five weeks of immersive reminiscence therapy improves autobiographical memory in Alzheimer's disease. Memory, 2018, 08. 09. 2018, pp. 1-14. https://doi.or g/10.1080/09658211.2018.1515960
FROMHOLT, Pia et al. Life-narrative and word-cued autobiographical memories in centenarians: Comparisons with 80year-old control, depressed, and dementia groups. Memory, 2003, vol. 11, no. 1, pp. 81-88. https://doi.org/10.1080/741938171

GURIAN, Elaine Heuman. Noodling Around with Exhibition Opportunities. In KARP, Ivan and Steven D. LAVINE (eds.).

Exhibiting cultures: the poetics and politics of museum display. Washington, D. C.: Smithsonian Institution Press, 1991, pp. 176-190. ISBN 1-56098-021-4.

HANSEN, Anna (ed.). Reminiscence in open air museums. Results from the Erasmus+ project Active Ageing and Heritage in Adult Learning. Östersund: Jamtli Förlag, 2017. ISBN 978-91-7948-258-9.

HEIN, George E. Learning in the museum. London: Routledge, 1998. ISBN 0-415-09776-2.

HUANG, Hui-Chuan et al. Reminiscence Therapy Improves Cognitive Functions and Reduces Depressive Symptoms in Elderly People With Dementia: A Meta-Analysis of Randomized Controlled Trials. Journal of the American Medical Directors Association, 2015, vol. 16, no. 12, pp. 1087-1094. https://doi. org/10.1016/j.jamda.2015.07.010

HUDSON, Kenneth. The Museum Refuses to Stand Still. Museum international, 1998, vol. 50, no. 1 , pp. 43-50. ISSN 1350-0775. https://doi.org/10.1111/14680033.00135

JENSEN, Jacob Thorek and Ida Brændholt LUNDGAARD. MUSEER - Borgere og Bæredygtige Løsninger [online]. København: Kulturstyrelsen, 2015 [accessed 2019-01-20]. Available from www: <https://slks.dk/publikationer/ museer-borgere-og-baeredygtigeloesninger/>. ISBN 978-87-90572-23-5.

KAVANAGH, Gaynor. Making histories, Making Memories. In KAVANAGH, Gaynor (ed.). Making histories in museums. London: Leicester University Press, 1999, pp. 1-14. ISBN 0-7185-0007-5.

KELLY, Matthews E., Victoria ANDREWS and Peter ADAMS. Social learning spaces and student engagement. Higher Education Research \& Development, 2011, vol. 30, no. 2, pp. 105-120. https://doi.org /10.1080/07294360.2010.512629

KINNEY, Jennifer M. and Clarissa

A. RENTZ. Observed well-being among individuals with dementia: Memories in the Making $($, an art program, versus other structured activity. American Journal of Alzheimer's Disease and Other Dementias, 2005, vol. 20, no. 4, pp. 220-227. https://doi. org/10.1177/153331750502000406

KOLB, David A. Experiential learning: experience as the source of learning and development. Englewood Cliffs, N. J.: Prentice-Hall, 1984. ISBN 0-13-295261-0.

KRYGER, Birgitte, Henning LINDBERG and Tove Engelhardt MATHIASSEN. Erindringsformidling - brobygning mellem det sociale og det kulturelle. Den Gamle By [Årbog], 2005, pp. 68-73.

LATHA, K. S. et al. Reminiscence Therapy: An Overview. Middle East Journal of Age and Ageing, 2014, vol. 11, no. 1, pp. 18-22. https://doi.org/10.5742/ MEAA.2014.92393

LINDBERG, Henning. The House of Memory. In HANSEN, Anna, Sofia KLING and Jakoba Sraml GONZALEZ (eds.). Creativity, Lifelong Learning and the Ageing Population. Fornvårdaren. Vol. 34. Östersund: Jamtli Förlag, 2013, pp. 94-101. ISBN 987-91-7948-246-6.

LUNDGAARD, Ida Brændholt and Anna Maria FOLDGAST. National brugerundersøgelse 2011. Copenhagen: Kulturstyrelsen, 2012. ISBN 978-87-91298-94-3.

Operational Guidelines For The World Heritage Committee 1977 (CC-77/ CONF.001) [online]. United Nations Educational, Scientific and Cultural Organization (UNESCO) [accessed 201901-20]. Available from www: <https:// whc.unesco.org/archive/opguide77a. pdf $>$.

Part 2: Evaluation of reminiscence activities. In HANSEN, Anna (ed.). Reminiscence in open air museums. Results from the Erasmus+ project Active Ageing and Heritage in Adult Learning. Östersund: Jamtli Förlag, 2017, pp. 17-37. ISBN 978-91-7948-258-9.

Part 4: Courses for professional care staff. In HANSEN, Anna (ed.). Reminiscence in open air museums. Results from the Erasmus + project Active Ageing and Heritage in Adult Learning. Östersund: Jamtli Förlag, 2017, pp. 41-49. ISBN 978-91-7948-258-9. 
RAVN, Thomas Bloch. The Modern Town Project at Den Gamle By. Den Gamle By [Årbog], 2007, pp. 72-75.

RAVN, Thomas Bloch. Den Gamle By. History and Future. Aarhus: Den Gamle By, 2009. ISBN 978-87-89328-45-5.

RAVN, Thomas Bloch. Meget mere end museum. Den Gamle By [Årbog], 2012, pp. 23-33.

RAVN, Thomas Bloch. Moderne tider på museum. In BAK, Lene et al (eds.). Kildekunst: historiske \& kulturhistoriske studier: festskrift til John T. Lauridsen. København: Museum Tusculanum, 2016, pp. 567-591. ISBN 978-87-635-4546-4.

Reminiscence therapy for dementia.

Cochrane Database of Systematic Reviews [online]. 2005, Issue 2, Art. No.: CD001120 [accessed 2019-01-20]. https:// doi.org/10.1002/14651858.CD001120.pub2

RENTZ, Clarissa A. Memories in the Making (C: Outcome-based evaluation of an art program for individuals with dementing illnesses. American Journal of Alzheimer's Disease \& Other Dementias, 2002, vol. 17, no. 3, pp. 175-181. https:// doi.org/10.1177/153331750201700310

RENTZHOG, Sten. Open Air Museums. The history and vision of a visionary idea. Stockholm: Carlson Bokförlag, 2007. ISBN 978-91-7948-208-4.

ROEDE, Lars. Flytting - forkastelig eller forsvarlig? Fortidsvern. Medlemsblad for Förtidsminneforeningen, 1999, vol. 25, no. 4, pp. 14-19.

ROEDE, Lars. Kopi og original - flytting og autentisitet. In AMUNDSEN, Arne Bugge, Bjarne ROGAN and Margrethe C. STANG (eds.). Museer i fortid og nåtid. Essays i museumskunnskap. Oslo: Novus forlag, 2003, pp. 117-141. ISBN 82-7009-374-3.

STJERNFELT, Frederik. Authenticities and their conflict: Genuine challenges of museology. In RAVN, Thomas Bloch and Elsebeth Aasted SCHANZ (eds.).
Authenticities and Relevance: Report from the 24th Conference in the Association of European Open Air Museums, Den Gamle By, Aarhus, Denmark 2009. Aarhus: Den Gamle By, 2011, pp. 40-59. ISBN 978-87-89328-59-1.

SUBRAMANIAM, Ponnusamy and Bob WOODS. The impact of individual reminiscence therapy for people with dementia: systematic review. Expert review of neurotherapeutics, 2012, vol. 12, no. 5, pp. 545-555. https://doi. org/10.1586/ern.12.35

The Nara Document on Authenticity [online]. International Council on Monuments and Sites (ICOMOS), 1994 [accessed 201901-20]. Available from www: <https:// www.icomos.org/charters/nara-e.pdf $>$.

The Operational Guidelines for the Implementation of the World Heritage Convention 2017 (41 COM 11) [online]. United Nations Educational, Scientific and Cultural Organization (UNESCO) [accessed 2019-01-20]. Available from www: <https://whc.unesco.org/en/ guidelines/ $>$.

Timetravel: Den Gamle By. Aarhus: Den Gamle By, 2018. ISBN 978-87-89328-95-9.

Turning back the hands of time: Autobiographical memories in dementia cued by a museum setting. Consciousness and Cognition, 2013, vol. 22, no. 3, pp. 1074-1081. https://doi.org/10.1016/j. concog.2013.07.008

What is social learning? Ecology and Society [online]. 2010, vol. 15, no. 4 [accessed 2019-01-20]. Available from www: $<$ http://www.ecologyandsociety.org/ vol15/iss4/resp1/>.

WILLIAMS-DAVIES, John. Now Our History is Your History: The Challenge of Relevance for Open-Air Museums. Folk Life. Journal of Ethnological Studies, 2009, vol. 47, pp. 115-123.

\section{MARTIN BRANDT DJUPDRAET}

Den Gamle By, Aarhus, Denmark mbd@dengamleby.dk

Head of research and presentation at the open-air museum Den Gamle By, Aarhus, Denmark since 2011. Master of Arts in History and History of Religions. Studies at University of Copenhagen and Charles University. Curator and organizer of several exhibition at Den Gamle By, Moesgaard Museum and The Viking Ship Museum in Roskilde. Author to article and books about museums practice and the use of history in art and culture. Research interest in the use of history, the museum as a social space and the museum institutes possibilities in dissemination practice.

Vedoucí výzkumu a prezentace ve skanzenu Den Gamle By ve městě Aarhus v Dánsku od roku 2011. Univerzitní diplom z dějin umění a historie náboženství. Studoval na univerzitě v Kodani a Karlově univerzitě. Kurátor a organizátor řady výstav v Den Gamle By, Moesgaard Museum a The Viking Ship Museum v Roskilde. Autor článků a knih o muzejní praxi a uplatnění historie v umění a kultuře. Zajímá se o využití historie, muzeum jako společenský prostor a praktické možností muzejních institucí při šǐrení znalostí. 